\title{
Baroque Trauerspiel in William Shakespeare's Hamlet: A Rejection of Aristotelian Tragedy
}

\author{
Abouzar Mostafalou \\ Department of English Literature, Karaj Branch, Islamic Azad University, Alborz, Iran \\ Hossein Moradi \\ Department of English Literature, Karaj Branch, Islamic Azad University, Alborz, Iran
}

\begin{abstract}
Tragedy, as a literary genre and a high form of literature, deals with lives of noble people. This type of drama is rooted in Aristotle's formulation which later has resulted into theory of drama known as Freytag's Pyramid. This model of drama which follows Greek version of tragedy has some common features including unity of time, place, and action. Moreover, the elements of death, language, and melancholy have been treated in the conventional ways in the genre $f$ tragedy. However, Walter Benjamin, the German philosopher and critic has opposed to the dominance of tragedy, and developed an independent genre called Trauer Trauerspiel in which ordinary people get to be the center of the play. Unlike tragedy which is based on myth, Trauer Trauerspiel is based on history that depicts the reality of life. Moreover, this genre has the trace of postmodern literature in which language has no meaning; death is treated in non-religious way, and melancholy is no longer considered to be a mental disease. By the same token, it could be claimed that Shakespeare's Hamlet, as a dominant form of tragedy, can no longer be considered as tragedy; since it repulses conventions of tragedy and Freytag's Pyramid, it belongs to a new genre, Trauer Trauerspiel in which Greek dramas' features can be dethroned and replaced by postmodern aspects of drama.
\end{abstract}

Index Terms-Baroque Trauerspiel, language, death, melancholia, Hamlet, Walter Benjamin

\section{INTRODUCTION}

Trauerspiel is a new literary genre for drama that opposes the traditional version of Greek literature. This genre has been developed by Walter Benjamin (1892-1940), the German eclectic thinker, cultural critic, and philosopher known as one of the Frankfurt School theorists. In his work, The Origin of German Tragic Drama (1928), Walter Benjamin refuses the traditional understanding of the Baroque Trauerspiel and tries to restore the value of this literary form as an independent genre of tragedy. By differentiating between Greek Tragedy and Baroque Trauerspiel, Benjamin Walter proposes Trauer Trauerspiel as an independent genre. To Walter Benjamin, the distinction between Tragedy and Trauerspiel is entirely based on linguistic and historical perspectives that are not end-and-perfection-based. Benjamin gives a whole view on writing and in the introduction of The Origin of German tragic Drama, he writes: "the writer must stop and restart with every new sentence. And this applies to the contemplative mode of representation... this form can be counted successful only when it forces the reader to pause and reflect” (Benjamin, 1998, p. 29).

Benjamin shows this genre as the combination of different aspects of history and language in construction of heroic or non-heroic action, pathological melancholy or non-pathological melancholy, named or namer, being catastrophic or a messianic redemption, and natural history. In contrast to Baroque Trauerspiel as an independent genre, the Greek Tragedy is a dead genre that belongs to a particular time and place. This genre, Baroque Trauerspiel, is based on characteristics which not only distinguishes it from tragedy but also carries it on postmodernism as a dominant genre.

For Benjamin, understanding of Trauerspiel can only be possible by uncovering its truth content and "acknowledging its distinctiveness" (Gilloch, 2002, p. 73). For Benjamin, distinguishing Trauerspiel from Tragedy is embedded in what has been shaped its dramatic plot structure; history and myth. Since the world based on myth is inherently law-making thus every action should be eschatological. Indeed, the idea of fulfillment of action and time which is the dominated idea in mythical world, as Greek Tragedy tries to demonstrate has an accomplished plot structure, it can be seen in the pyramid drawn by Freytag on Aristotle principle. However, in Trauerspiel history which is entropy-based draws the truth content of the world which is deprived of any potentiality for salvation, progress or redemption and it is quite against the conventional roles in developed by Aristotle. That is why every human deed in Trauerspiel doomed to futility unlike tragedies.

William Shakespeare (1564-1616) is known among critics and playwrights and as the creator of masterpieces, not only in drama but also in poetry. He wrote 36 plays that could be classified in three groups, comedies, histories and tragedies collected in the First Folio of 1623. As a tragic playwright, Shakespeare created 12 tragedy that are the masterpieces of the tragic literature of which Hamlet (1605) is the most important and the most recognized tragedy. This play narrates the story and of life of a Danish prince which is dethroned after his uncle assassinates his father and 
marries his mother. This prince cautiously identifies himself as mournful prince to reveal the truth of his father's death. Step by step, he moves toward madness and melancholy that occurs consciously and unconsciously.

\section{Methodology}

To distinguish Baroque Trauerspiel from Greek Tragedy in the introduction to this work, the "Epistemo-Critical Prologue", Benjamin sketches a unique methodology which is quite self-dependent. This "treatise as a method is" blended with "digression" so that objectively is drained of any "conclusiveness" (Salzani, 2008, p. 20). To show that Trauerspiel can be considered as independent genre, there are some key terms that must be studied. Melancholy and language are two significant features of Trauerspiel genre that can distinguish it from Greek tragedy. It is known that melancholy comes from Freud's remarks in psychology. Freud depicts a pathological disposition of human subjectivity which is strongly visible in the characterization of melancholy. Accordingly, Freud traces mourning and melancholia as two contradictory mental beings originated from the patient's responses to the bereavement and loss. Freud distinguishes between these two concepts: Mourning can be considered as the gloomy reaction to the loss of a loved object which can be taken over by passing of time while melancholia does not leave the subject, and like a ghost, it haunts the person throughout his entire life and drives into madness.

For Freud the division between mourning and melancholy is the result of reaction to loss imposed on someone. In this, the lost-object which is "intimately tied to love" (Ferber, 2013, p.21) could be a person or an ideal. In this condition, the mourning causes the person to not only clearly identify the lost-loved object but also detaches himself from it through bemoaning and wailing, while melancholy "remains sunken in his loss" (Ferber, 2013, p.21). Indeed, melancholia knows "whom he has lost but not what about him was lost" (Ferber, 2013, p.21). Unlike mourning in which it completely detaches itself from the dead-object and permit it to leave, Melancholy internalizes it in his ego, and thus "the lost object continues to exist ... as part of the dejected subject" (Ferber, 2013, p.20), consequently it is difficult to "define the borders between [one's] subjectivity and ... the lost object within it" (Ferber, 2006).

Benjamin, in Trauerspielbuch challenges the Freudian fixed distinction between mourning and melancholy, and renounces indirectly the Freudian pathological understanding of Melancholia, and thus he uses the melancholy and mourning interchangeably. It has been said that "Benjamin's annotations to the engraving and his concept of melancholy stand in a direct relation to... [the period which Melencolia I belongs]... Baroque...” (Goebel, 2009, p. 57). Freudian idea for Benjamin is nothing but a narcissistic way that leads to narcissism. A melancholic person inevitably reaches a state in which the world with all its natural and human laws presented as a mask decoration after losing the love-object in a moment. In fact, he realized the truth of the world that the loss in the world as condition of possibility is prominent deficit not transitory. And here the differences clear out; indeed, Freud wants you to forget not only the lostobject but also the loss as condition of possibility and with selecting new love-object again returns to the world of masks that calls it back to reality.

This sense of loss and melancholy is very significant for Benjamin; despite the "certain superficial resemblance" between Trauerspiel and Tragedy (Gilloch, 2002, p.73), For Benjamin Nothing distinguishes Trauerspiel from tragedy more clearly than" (Gilloch, 2002, p.78) its tendency toward loss; indeed, Loss is not only presented in the content but also in the structure of Trauerspiel genre and it is because in the Benjamin's view, "history was the source of Trauerspiel" (Gilloch, 2002, p.75). Therefore, the focus of the used method in this essay would on finding this kind of feeling.

Language and death are the other elements that must be found in Hamlet; however, these concepts must be distinguished and elaborated at first. Aristotle, by definition of tragic plot, the most important play element, in fact, constructs an idealistic system, which is aimed to form a whole. Then, accordingly "the task of tragic plot (muthos), is [nothing but] to render an ideal action [_ a beginning-middle-end structure] in terms of stage-event;" but such action in the ideal form "may [not] succeed in" (Jones, 1962, p. 31) "the deliberate selection and arrangement of the incident" (Rush, 2005, p. 63) "without having recourse to" the Newtonian relative time in linear trend. (Jones, 1962, p. 31). However, in postmodern era, the linearity is replaced by non-linearity of events.

The distinction that Benjamin makes in "Trauerspiel and Tragedy" was origined from the difference between Tragedy and Trauerspiel considered in context. He considers the basic difference in the different attitudes of the two genres towards historical time and says that Greek Tragedy is constructed on mythical time while in Trauerspiel the time has a historical background. Benjamin believes that the mythical time in Greek Tragedy causes the motion of the relative time in linear trend and triggers the transformation of Greek Tragedy's State of Equilibrium to the New State of Equilibrium. To show this difference, using figures - the first one for tragedy and the second one for Trauerspiel - can be helpful. 


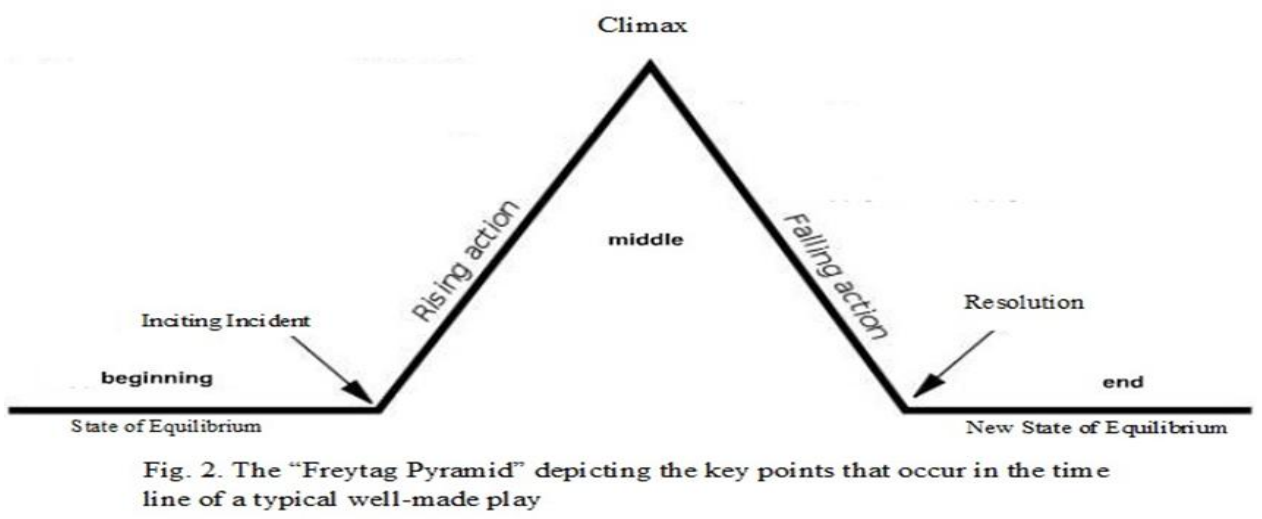

It's the diagram form of a triangle to chart five basic component of dramatic structure which follows Aristotle's theory on the unity of dramatic plot_ beginning, middle and end; namely State of Equilibrium, Rising action, Climax, Falling action, and New State of Equilibrium. "This three-step breakdown [, beginning-middle-end structure]... as a whole ... can be applied to all actions, large or small", even in the Newtonian laws of motion ${ }^{1}$, in the natural world, we see such a whole unity. In fact, "the heart of a dramatic action is the series of events that lead to a significant change taking place in a specific situation. Thus, we have a period of time before that change starts to happen, a part that takes us through the process of change, and the part afterward. Since the meaning of the play is found by contrasting how the ending differs from the beginning..." (Rush, 2005, p. 38). However, Trauerspiel's dramatic structure consists of two parts, a decisive part_ the middle that is included components such as Ex-climax, Natural History and Climax, alongside a non-obligatory part_the beginning which can be omitted.

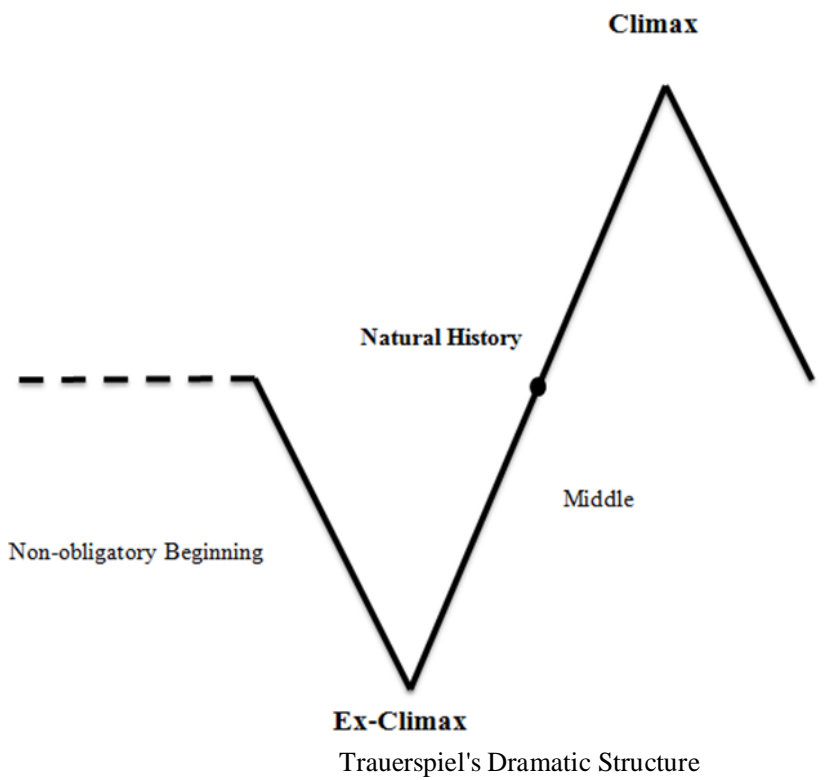

From Benjamin's view, the world of tragedy is always expectant of new rules and these rules cannot be achieved unless in the end which represents itself in the death of the hero. Death as a whole has meaning because death is the end of life; however, in Trauerspiel, for Benjamin the status of Death is always accompanied by the utter indeterminacy which in his "Trauerspiel and Tragedy" (1916) puts it in this way: A tragic death is an ironic immortality, ironic from an excess of determinacy. The tragic death is over-determined... Death in Trauerspiel... is no conclusive finality... Its events are allegorical schemata, symbolic mirror-images of a different game. We are transported into that game by death" (Bullock I, 1996, p. 56-7). The status of death in tragedy means the stop and end of not just life but also the misery of it through the providing death as rest and solution; on the contrary, death in Trauerspiel indicates the opposite marks of death. Therefore, finding such a death which is not the end of life would be another task of this essay.

\footnotetext{
${ }^{1}$ The great seventeenth-century English mathematician Sir Isaac Newton tells us that a body at rest will remain at rest until something sets it in motion A ball does not start rolling until somebody pushes it. Then the ball rolls, and after a while, it comes to rest again.( David Rush A Student Guide to Play Analysis Southern Illinois University Press 2005 p. 38)
} 
It has been argued that "there is an essential connection between" the tragic action and tragic language for giving meaning to life (Bullock I, 1996, p. 56). For Benjamin Greek Tragedy genre is based on human speech. He stresses on this point that tragedy is dialogue-based genre. In tragedy, dialogue is the instrument of communication for transferring the significance which is the idea of tragedy. Such outlook of tragedy elucidates it certainly as a goal-oriented genre; a goal that always is achieved at the end. However, in Benjamin's Trauerspiel, there exist a relationship between language and mentality. In mental pain the mourner tries to transcend his individual pain through the transferring his anguish into the public communal utterance through the communication. For this reason "man communicates his own mental being in his language" (Bullock I, 1996, p. 64). However, this pain and suffering are the result of the inability of human language to express itself. In the other words this is not the lost-object but the language itself through the inability in expression and extending immediately that creates melancholic situation. Therefore, showing inability of language to transfer mental state of the main character would be another scope of this essay.

\section{ANALYSIS AND DISCUSSION}

Death and Language in Hamlet as a Trauerspiel

It is known that in the Freytag's Dramatic Structure, in which "Death is a refuge from all" (Grady, 2009, p. 161), pain and suffering, "the sense of loss... is firmly implanted in" (Grady, 2009, p.161). Indeed, in Trauerspiel's diagram unlike the Greek Tragedy, one does not have any State of new equilibrium which is always tied with the emergence of new rule and the determination of all miseries; the lost-avoidance procedure introduces Death as an end. Such archaic intuition about the matter of death as a commercial fact is visible -can be seen even in helmet himself in the first time that he faces the ghost:

HAMLET

O, answer me!...

Why thy canonized bones, hearsed in death,...

That thou, dead corse, again in complete steel

Revisit'st thus the glimpses of the moon,

Making night hideous; and we fools of nature

So horridly to shake our disposition

With thoughts beyond the reaches of our souls? (1. 4. 49)

For Hamlet, death means the determination of one's suffering and reaching quietly the rest through canonization. Then it is not conceivable for a person like Hamlet that how it can be possible for a dead body to revisit.

The ghost reveals far more beyond the Hamlet new intuition that the death is not the rest of the dead person, so that it "Would harrow up thy soul, freeze thy young blood," and "Make thy two eyes, like stars, start from their spheres". Indeed, for the ghost of the king, the dead body not only did the misery and pains not "come to rest," but also they were accompanied with severe and intolerable and tough tortures in the "sulphurous and tormenting flames" (1. 5. 55)

But the matter of Death as un-mitigation does not limit the Ghost of the dead body that is resurrected. Indeed, the death of other characters, either the main character or not, against the tragic hero whose death brings the new state of equilibrium as a conclusive end, always remains un-resulted and un-finalized. And Hamlet is the main character of a Trauerspielian drama that is not excluded from this rule. Hamlet himself in this regard says:

\section{HAMLET}

To be, or not to be: that is the question:

Devoutly to be wish'd. To die, to sleep;

To sleep: perchance to dream: ay, there's the rub;

For in that sleep of death what dreams may come

When we have shuffled off this mortal coil, (3.1. 119-120)

He raises the question whose answer he knows well. He knows that there is no difference between being a worrier who faces all the "sea of troubles" or a "nobler" (3. 1. 120) because of that Death does not finish the miseries, not only just the misery of the main character as Hamlet himself but also the human world's profane misery. Indeed, Hamlet is aware of the fact that his death does not bring peace for himself.

This sense toward death among other things as the ghost's free movement we see in the first scene of the first act that disturbs the Jetztzeit, the relation between chronological time with action, "embodies Hamlet's sense of the lost world of immanent meaning[s]"(Grady, 2009, p. 161). So that, "Hamlet reacts to the death of his father as the death of [his] entire world view" (Grady, 2009, p. 161):

HAMLET

....and indeed it goes so heavily

with my disposition that this goodly frame, the earth, seems to me a sterile promontory, this most... what is this quintessence of dust? man delights not me: no, nor woman neither, though by your smiling you seem to say so. (2. 2. 97) 
Hamlet aligns with the play trying to disengage "from what had been, before the death of his father, a meaningful, epic, immanent world" which is the features of the mythical world and a step forward to the real world in which time and action are two completely separate things(Grady, 2009, p.160-1). Then, the world that Hamlet describes, what Benjamin means real world, indeed, is nothing just the post-fall world. As it has been said before Man after the Sin was expelled from Eden and exiled to this world, the profane world, the world in which "both [Man's] words and actions" (Grady, 2009, p.164) cannot bring back the thing which is lost.

Such "[profane] world ... [after The Fall] is an alien collection of objects seeking meaning and significance," (Grady, 2009, p.155) however, after The Fall, human language in contrast to the paradise language loses "the natural correlation between word and thing" (Grady, 2009, p. 144). This is a "cut off from higher meaning" (Grady, 2009, p.) that Benjamin expresses it as Naming changes to Overnaming.

And Hamlet in facing Ophelia's father, Polonius, as a post-fall man begins to correlate between word and objects:

LORD POLONIUS

My lord, the queen would speak with you, and presently.

HAMLET

Do you see yonder cloud that's almost in shape of a camel?

LORD POLONIUS

By the mass, and 'tis like a camel, indeed.

HAMLET

Methinks it is like a weasel.

LORD POLONIUS

It is backed like a weasel.

HAMLET

Or like a whale?

LORD POLONIUS

Very like a whale. (3. 2. 153)

Hamlet more than plays with Polonius, as a namer tries to find a name for the cloud which is in motion. Such action reminds us of "Adam's naming of the animals and other things of the world in Genesis," but with the difference, as Benjamin says that "out of paradise, human language begins to lose the Adamic, natural correlation between word and thing[s]"( Grady, 2009, p. 139.144).In addition, this section of Hamlet not only does represent the lack of human's capability to name objects, but it also warns that Nature itself can never be the name. And this is only because Nature in absolute time as a cloud which Hamlet refers to does not have a stable shape and is constantly being deformed.

Benjaminian Melancholy in Hamlet

Unlike "the older attempt to describe" (Pensky, 1993, p.90) the character Hamlet as one who transforms from the state of mourning to melancholia, for Benjamin "Hamlet is the figure in which melancholy (Rice, 2009, p. 106)... [Is] tied with incompleteness time" (Rice, 2009, p. 173) of the Trauerspiel dramatic structure. Hamlet as a main character of Trauerspiel genre is not classified in any way in the pathological Freudian dissociation between mourning and melancholia.

Trauerspiel genre's dramatic structure in contrast to the tragic one completely forms the basis of the middle part that consists of ex-climax, Natural history and climax. And this is the middle part of the Trauerspile dramatic structure that rejects all the Freudian pathological attitude toward characters like Hamlet, and therefore inaugurates a nonpathological one.

Hamlet, as "a stranger's eyes"(Cantor, 1989, p. viii) ,following the loss of his father changed his worldview, in the ex-climax of Treauerspiel, "keenly"( Cantor, 1989, p. viii) begins the Natural history for disclosing the truth of the fallen world through the distraction of the pre-accepted process by the community: Historical fate. This is why the disclosing of the truth of the object "lies [in] paradox: the only way to [attain the truth] is to destroy it." (Ferber, 2013, p. 59)

In Hamlet, the Historical fate in the matter of the loss of the object of love is formed on the Freudian thinking about the loss and how to deal with it. In the first meeting between Hamlet and the new king, in which Hamlet is dressed in black for the loss of his father, Claudius as the ruler and the voice of community pointes out to the Historical fate:

KING CLAUDIUS

'Tis sweet and commendable in your nature, Hamlet,

To give these mourning duties to your father:

But, you must know, your father lost a father;

That father lost, lost his, and the survivor bound...

This unprevailing woe, and think of us

As of a father: for let the world take note,

You are the most immediate to our throne;

And with no less nobility of love

Than that which dearest father bears his son, (1. 2. 25) 
Claudius as new king of Denmark explains to Hamlet that death is a natural and normal process that is not to be prevented which "you must know [that if you lost your father,] your father lost a father [and] that father lost" a father too and being in sorrow is acceptable and admirable but only when the period of mourning be short. Actually, from the perspective of Danish society, mourning is a duty, social or religious, but any form of transgression of normal treatment in which indicates the "heart unfortified [and the] mind impatient" of mourner severely criticized and condemned. In this regard, they believe that a man must avoid any form of "unmanly grief" by filling the emptiness of that loss with a new love-object.

Therefore, Hamlet's uncle expresses the social view that wholly follows the Freudian pathological thinking on the matter of loss and wants Hamlet to answer the call of reality through choosing him as his new father. Such historical fate in Denmark is so strong that the queen, Gertrude, after the loss of her husband, the previous king of Denmark, remarried her husband's brother and because of that is firmly criticized by Hamlet:

HAMLET

Look here, upon this picture, and on this,

The counterfeit presentment of two brothers.

See, what a grace was seated on this brow;

Hyperion's curls; the front of Jove himself;...

Could you on this fair mountain leave to feed,

And batten on this moor? Ha! have you eyes?

You cannot call it love; for at your age

The hey-day in the blood is tame, it's humble,

And waits upon the judgment: and what judgment (3. 4. 167)

Gertrude's desertion and remarriage with Claudius as Hamlet mentions it correctly is not the result of the outpouring of the sensuality of the old queen because the age always adds to the mind and reduces passion. Then how could it be possible an old person as the queen remarries shortly after her husband's death? And the answer is that the old more than the young is the peremptory follower of the Historical fate. Moreover, Gertrude's sex as a female intensifies her obedience of the Freudian ideas of the society about loss.

Then in such a community, the behavior of people like Hamlet, in the eyes of others is an "antic disposition"(Rice, 2009, p. 167) which causes him to be known as a melancholic one, whether it is the reason for people like Polonius about Hamlet's love for Ophelia or the hasty remarriage of his mother from the queen's perspective. However, although Hamlet, as he describes his task, the Natural history, for the queen, is "a glass [that] you may see the inmost part[s] of" (3. 4. 163) human existence, and somehow Polonius points it that "Though this be madness, yet there is method/in 't... (2. 2. 91) but still "his anti-social behavior" from people's perspective "gives ...good reason" for them "to fear him as a menace to the state" (Cantor ix) and consider him mad. Indeed, such a reaction by others, the Double-alienation that pushes Hamlet to death in the Trauerspiel's climax, is originated from their commitment to Historical fate.

Accordingly, such intuition to melancholy even answers "the question which has preoccupied critics of Hamlet...: why does the prince delay in taking his revenge on the man who murdered his father?" (Cantor, 1989, p. 20); although his father is murdered by one who usurps this was the loss of his father that let him to face the truth of a profane world which has fallen, animate or inanimate.

But in Hamlet there is another one who is so close to the Freudian melancholy: Ophelia. She faces two kinds of loss; the loss of her lover and after that her father, which paralyzed her. In the matter of the loss of Hamlet, her lover, Ophelia passively obeys her father and turns away from being a beloved to a spy, however, she really loves him. And similarly later, in her father's loss, we see such passivity:

\section{QUEEN GERTRUDE}

There, on the pendent boughs her coronet weeds

Clambering to hang, an envious sliver broke;

When down her weedy trophies and herself

Fell in the weeping brook. Her clothes spread wide;

And, mermaid-like, awhile they bore her up:...

Till that her garments, heavy with their drink,

Pull'd the poor wretch from her melodious lay

To muddy death. (Act IIII scene 7)

The Queen express to Laertes and Claudius how Ophelia's clothes after she falls in the water is slowly filled with water and drowns her while she does not attempt to rescue herself. Accordingly, we can firmly say Hamlet, unlike Ophelia, has no sign of the Freudian melancholia as a dilemma, sloth and acedia. However, the majority, compared with Laertes in taking revenge on the Polonius's murderer, accuses Hamlet of dilemma in action. But for Benjamin "Hamlet's dilemma is a matter not of personal failure" (Cantor, 1989, p. xiii). In fact, for Benjamin, the prince's delay "in taking revenge on the man who murdered his father... as soon as he learns of the guilt of" him (Cantor, 1989, p. 20) after the act of the murder of king Gonzago originated from "the absurdity of action itself in a corrupt world" (Cantor, 1989, p. xiii). Hamlet as one who is under the Benjaminian melancholy knows well that the post-fall world does not have the capability to fulfill an action. So the revenge will not terminate the fratricide. 


\section{CONCLUSION}

Having analyzed, the play of Hamlet, it could be said that Hamlet is a tragedy, However, it is not entirely complies with the Aristotelian principles of Tragedy. In this essay, three key terms have been applied to the play; unlike Greek tragedy, for Hamlet death was not the end of life. In fact, death and life were merged together and provided a new aspect of tragedy which was depicted by presence of the ghost. In Hamlet, the ghost of a dead man who calls himself, the king not only is not separated from the world of living but also as a living king wants prince Hamlet to swear and take the ghost's revenge from Claudius. The existence of a ghost and the duty that binds Hamlet and reveal the loss of eschatology; the lack of judgment day puts the duty of revenge on ghost's son. As if, that death has never been the end of life.

Regarding language, "to the death of fixed meaning" (Makidon, 2004, p. 19) could be traced throughout the play. In this play, language does not possess duality of polar concept to decipher meaning; in fact, the convention duality of pairs is absent, and meanings cannot be realized. Shakespeare through his character prince Hamlet as a person who has postmodern mind tries to destroy the centrality of meaning not only in his sentence but also in the others through the presence of the absent part of a word or sentence. Therefore, language cannot convey Hamlet's state of mind which paves the way for the third key term, melancholia. In this regard, melancholia is no longer a mental disease; rather, it is entering into reality of the world which is not based on the world of myth but history. Consequently, it can be said that Hamlet does not belong to the genre of Greek tragedy developed by Aristotle; rather, it belongs to Benjamin's genre of Trauerspiel as a postmodern literature.

\section{REFERENCES}

[1] Benjamin, W. (1998).The Origin of German Tragic Drama. Trans. John Osborne. London: Verso Books.

[2] Bullock, M. and Michael W. Jennings, eds. (1996). Walter Benjamin Vol. 1: Selected Writings, 1913-1926.4th ed. Cambridge, MA: Harvard University Press.

[3] Cantor, P. (1989). A. Shakespeare: Hamlet. United Kingdom: Cambridge University Press.

[4] Ferber, I. (2006). "Melancholy Philosophy: Freud and Benjamin." E-rea 4.1. n.pag. Web.

[5] Ferber, I. (2013). Philosophy and Melancholy: Benjamin's Early Reflections on Theater and Language. United States: Stanford University Press. Print.

[6] Gilloch, G. (2002). Walter Benjamin, Critical Constellations. Cambridge, UK: Polity.

[7] Goebel, R.J. (2009). ed. A Companion to the Works of Walter Benjamin. Rochester, NY: Boydell\& Brewer.

[8] Grady, H. (2009). Shakespeare and Impure Aesthetics. United Kingdom: Cambridge University Press.

[9] Jones, J. (1962). On Aristotle and Greek Tragedy. United States: Stanford University Press.

[10] Makidon, M.D. (2004). Postmodernism: the death of god and the rise of the community. Grace Evangelical Society Journal, 17(32), 15-31.

[11] Pensky, M. (1993). Melancholy Dialectics: Walter Benjamin and the Play of Mourning. United States: University of Massachusetts Press.

[12] Rice, C. (2009). Walter Benjamin and the Architecture of Modernity. Ed. Andrew Benjamin. Australia: re.press.

[13] Rush, D. (2005). A Student Guide to Play Analysis. New York, NY, United States: Southern Illinois University Press.

[14] Salzani, C. (2008). Constellations of Reading: Walter Benjamin in Figures of Actuality. New York: Verlag Peter Lang.

[15] Shakespeare, W. (1988). Hamlet, Prince of Denmark. Eds. David Bevington and David Kastan. New York: Random House Publishing Group.

\footnotetext{
Abouzar Mostafalou was born in Minudasht, Iran, in 1989. He received his M.A. degree in English literature from Islamic Azad University Karaj Branch, Iran in 2016. His research interests include philosophy and literature specially Walter Benjamin's ideas.
}

Hossein Moradi was born in Kermanshah, Iran. He received his Ph.D. in English literature from Manchester University in England in 2011. Currently he is an assistant professor in the Islamic Azad University, Karaj branch, Iran. His research interests include Deconstruction. 